\title{
Consequences of light reduction for anti-herbivore defense and bioactivity against mussels in four seaweed species from northern-central Chile
}

\author{
Christian Pansch ${ }^{1, *}$, Osvaldo Cerda ${ }^{2}$, Mark Lenz ${ }^{1}$, Martin Wahl ${ }^{1}$, Martin Thiel $^{2,3}$ \\ ${ }^{1}$ Leibniz Institute of Marine Sciences at the University of Kiel, IFM-GEOMAR, Marine Ecology, Düsternbrooker Weg 20, \\ 24105 Kiel, Germany \\ ${ }^{2}$ Departamento de Biología Marina, Facultad de Ciencias del Mar, Universidad Católica del Norte, Larrondo 1281, \\ Coquimbo, Chile \\ ${ }^{3}$ Centro de Estudios Avancados en Zonas Aridas, CEAZA, Coquimbo, Chile
}

\begin{abstract}
It is widely assumed that the production of secondary metabolites against grazing and fouling is costly for seaweeds in terms of metabolic energy and should therefore be reduced under conditions of resource limitation. Here we tested the hypothesis that anti-herbivore defenses and bioactivity against mussels in 4 brown seaweeds from northern-central Chile will be reduced when light is limited. In a 2 wk experiment, seaweeds were kept under different low-light conditions ( 76 to $99 \%$ reduction of ambient sunlight) and grazing situations. Subsequently, we tested their antiherbivore defense against a common amphipod grazer in feeding assays with living algal tissue and reconstituted food pellets. A standard test employing the production of byssus threads by mussels was furthermore used as an indicator for deterrents in crude algal extracts. All investigated seaweeds showed decreased growth under the stepwise light reduction. Lessonia nigrescens exhibited reduced defense ability under severe low-light conditions when living tissue was offered to the amphipod, probably caused by changes in the tissue structure or in nutritional traits. In Dictyota kunthii, L. trabeculata and Macrocystis integrifolia this effect was absent. None of the investigated seaweeds showed a clear effect of light reduction on chemically mediated defenses against the mesograzer and there was no effect of light limitation on the bioactivity against mussels. Thus, against general assumptions, chemical defense in the investigated seaweeds does not appear to be reduced under severe resource limitation. Results suggest that seaweeds may use different strategies of energy allocation to cope with low-light conditions.
\end{abstract}

KEY WORDS: Seaweeds $\cdot$ Macroalgae $\cdot$ Chemical defense $\cdot$ Light limitation $\cdot$ Herbivores $\cdot$ Fouling

\section{INTRODUCTION}

In most marine environments, seaweeds are exposed to grazing by generalist and specialist herbivores (Lubchenco \& Gaines 1981, Jormalainen \& Honkanen 2008), as well as to fouling pressure by epiphytes (Seed 1985) and sessile invertebrates (Dixon et al. 1981, see also Steinberg \& de Nys 2002, Lane \& Kubanek 2008). Both grazing and fouling can have profound negative impacts on algal performance (Dixon et al. 1981, Can- cino et al. 1987, Saier \& Chapman 2004). Many algal species have evolved strategies to reduce the negative influences of grazing via morphological, associational, nutritional and chemical defenses (Duffy \& Hay 1990, Cronin 2001), while fouling is predominantly diminished through surface-bound chemicals (Schmitt et al. 1995, Jennings \& Steinberg 1997, Lau \& Qian 1997, 2000).

Numerous studies focusing on the field of chemical defenses have demonstrated the efficiency of algae- 
produced compounds (e.g. phlorotannins or terpenes) in preventing grazing and fouling (reviewed in Steinberg \& de Nys 2002, Amsler \& Fairhead 2005). However, studies on alga-herbivore interactions have shown that the impacts of chemical substances on grazers are highly variable, depending on the grazer species (Amsler 2001, Rothäusler et al. 2005) as well as on the life history of both the herbivore and the alga (Cronin \& Hay 1996a). On the other hand, herbivores are considered to be mainly N-limited, and therefore selective in foraging for N-rich algal tissue (Mattson 1980, Duffy \& Paul 1992, Cruz-Rivera \& Hay 2000, 2003).

One of the most important questions that remains to be answered regarding defensive traits in seaweeds is when and how much energy should (and can) be allocated to defense. It is widely assumed that defensive compounds in algae are synthesized via secondary metabolic pathways, although some have recently been shown to have primary functions (Amsler \& Fairhead 2005, Maschek \& Baker 2008). Deterrents can be produced constantly (constitutive defense) or modified in response to grazing pressure (induced defense) (Cronin \& Hay 1996b, Taylor et al. 2002, Macaya et al. 2005). Numerous hypotheses (reviewed in Cronin 2001, Stamp 2003, Pavia \& Toth 2008) seek to explain the allocation of energy resources in plants. However, the basic assumption is usually that the production of defensive compounds is costly in terms of metabolic energy and resources because there must be a tradeoff between the production of secondary metabolites and plant or seaweed growth, maintenance or reproduction (Rhoades 1979, Fagerström 1989, Van Dam et al. 1996, Arnold \& Targett 1998, Pavia et al. 1999).

The environmental stress theory predicts a reduced investment of energy and resources into defense and enhanced investments into maintenance under conditions of environmental stress (Rhoades 1985, Cronin 2001). Consequently, any environmental stress, as well as the limitation of resources, in a given habitat should reduce the potential of seaweeds to defend themselves against grazing and fouling. In this context, the widely accepted growth-differentiation balance hypothesis predicts that with decreasing light availability for photosynthetically active organisms, their chemically mediated defenses will decrease (Stamp 2004). In general, both hypotheses predict a decrease in the amounts of chemical defenses with decreasing light availability (Cronin 2001, Stamp 2003, 2004).

While these theoretical considerations assume that defenses are costly and therefore reduced under resource limitation and environmental stress, this common assumption has rarely been tested in experimental studies (but see Dworjanyn et al. 2006). Some indication for the described negative effects of stress on defenses in seaweeds comes from observational studies. For example, Haggitt \& Babcock (2003) found that after severe storms, damaged or bleached tissues of Ecklonia radiata (Laminariales) were preferably consumed by the amphipod Orchomenella aahu. In 2 studies on chemically mediated defense, a negative relationship between algal growth and secondary metabolite production such as phlorotannins was interpreted as evidence for the metabolic costs of chemical defenses (Steinberg 1995, Pavia et al. 1999). However, the significance of these findings has recently been questioned by Arnold \& Targett (2003) since the observed relationship might also be due to the allocation of phlorotannins to the formation of cell wall structures (Schoenwaelder \& Clayton 1999). Experimental studies examining direct stress effects on algae secondary metabolites showed that, for example, desiccation and herbivory affects important life-history functions of $\mathrm{Fu}$ cus gardneri such as survivorship, growth, reproduction and secondary metabolite concentrations (Dethier et al. 2005). Stressful conditions such as exposure to air, excessive sunlight and herbivory were also shown to reduce the capability of Dictyota ciliolata to produce secondary metabolites (Cronin \& Hay 1996a,c).

An important stressor for algae can be solar radiation and both high and low radiation levels may negatively affect algal performance (Cronin \& Hay 1996c, Véliz et al. 2006, Gómez et al. 2007). Light reduction strongly affects the energy budget of algae, as well as the amount of carbon available for life processes and for the production of defensive metabolites (Cronin \& Hay 1996c, Pavia \& Toth 2000, Stamp 2004). Assuming that defense is costly, limited energy and resources should result in lower growth rates and reduced defense capabilities. In the present study, we tested the hypothesis that anti-herbivore defenses and the bioactivity of algal crude extracts against mussels in brown seaweeds (Dictyotales and Laminariales) from northern-central Chile will decrease under stepwise light limitation and will also be affected by the presence of grazers. Two assays of anti-herbivore defense were used to test for defense traits in seaweeds exposed to different shading regimes and grazing situations: (1) feeding assays in which we offered living algal tissue to amphipods and (2) assays with food pellets loaded with extracts from the treated algae. We also used a mussel test in which we measured the activity of mussels in producing byssus threads in response to different algal extracts as a further indicator for bioactive chemicals.

\section{MATERIALS AND METHODS}

Study sites and organisms. The experiment was conducted during austral summer 2007 using the outdoor laboratory facilities at Universidad Católica del Norte, 
Coquimbo, Chile. We included 4 brown algae species in the present study: Dictyota kunthii (C. Agardh) Greville 1830, Lessonia nigrescens Bory 1826, L. trabeculata Villouta \& Santelices 1986 and Macrocystis integrifolia Bory 1826. Adult specimens of D. kunthii (studied previously under the name Glossophora kunthii) have been shown to be chemically defended and to induce defenses under grazing pressure (Macaya et al. 2005, Rothäusler et al. 2005). Previous experiments with $L$. nigrescens indicated that young sporophytes of this species are defended against mesograzers (Rothäusler \& Thiel 2006), possibly due to high contents of phenolic compounds (Martinez 1996). Sporophytes of $L$. trabeculata were less defended than $L$. nigrescens (E. Macaya et al. unpubl. data), and $M$. integrifolia has no or only very limited chemical defense against amphipod grazers (Macaya et al. 2005, Macaya \& Thiel 2008). Consequently, consumption of the latter 2 species should be relatively unaffected by resource limitation, while consumption of the first 2 species are expected to increase when resources are limited.

We used young specimens (sporophytes) of Lessonia nigrescens and the closely related species $L$. trabeculata because of the logistic restrictions of the small experimental aquaria (2 1). Apical parts of the thallus (consisting of a stipe holding several blades) of the large kelp Macrocystis integrifolia were successfully used in previous experiments and continue to grow during experiments (Macaya et al. 2005, Rothäusler \& Thiel 2006). Adult Dictyota kunthii were collected from shallow subtidal sand flats in Totoralillo $\left(30^{\circ} 04^{\prime} \mathrm{S}\right.$, $71^{\circ} 22^{\prime} \mathrm{W}$ ), where they grow attached to boulders ( 2 to $4 \mathrm{~m}$ depth). The seaweed L. nigrescens was sampled in an exposed rocky intertidal zone at La Pampilla, Coquimbo $\left(29^{\circ} 57^{\prime} \mathrm{S}, 71^{\circ} 20^{\prime} \mathrm{W}\right)$, and L. trabeculata came from a subtidal rocky habitat (4 to $6 \mathrm{~m}$ depth) near Lagunillas $\left(30^{\circ} 06^{\prime} \mathrm{S}, 71^{\circ} 23^{\prime} \mathrm{W}\right), 20 \mathrm{~km}$ south of Coquimbo. The giant kelp $M$. integrifolia was collected in the subtidal zone of Punta de Choros $\left(29^{\circ} 14^{\prime} \mathrm{S}\right.$, $\left.71^{\circ} 28^{\prime} \mathrm{W}\right)$.

The amphipod Parhyalella penai Pérez-Schultheiss \& Crespo, 2008 (called $P$. ruffoi in previous studies) was used for tests of algal palatability. This grazer is a generalist mesograzer that feeds on a wide variety of different seaweeds, including the 4 investigated species (Macaya et al. 2005, Rothäusler et al. 2005). P. penai occurs in high abundances in accumulations of diverse drift algae in the shallow subtidal zone of sheltered beaches from northern-central Chile. Amphipods were collected from Playa Chica of Bahía La Herradura, Coquimbo by collecting accumulations of drift algae. The amphipods were separated from the algae by gently shaking them over a large tray filled with seawater. The mussels Perumytilus purpuratus Lamarck, 1819 and Semimytilus algosus Gould, 1850 (Bivalvia, Mytilidae) were used as indicators for the presence of bioactive compounds in algal extracts. Specimens of $P$. purpuratus (body length $\sim 2.7 \pm 0.4 \mathrm{~cm}$ ) and $S$. algosus (body length $\sim 2.0 \pm 0.3 \mathrm{~cm}$ ) were collected from rocks at low tide from the intertidal zone of Totoralillo. To avoid injuries to the byssus apparatus, we loosened the mussels carefully from their natural substratum. After collection, they were kept for a few days in a $70 \mathrm{ltank}$ with flowing seawater and an air supply before the start of the mussel test.

Identification of light compensation points. In order to determine physiologically meaningful levels of low light, we assessed the light compensation point (LCP) for each of the 4 algal species. For this, plastic aquaria (2 l) were wrapped in aluminum foil and completely filled with seawater. A transparent glass plate served as a lid to prevent the exchange of gas with the atmosphere and to hold layers of black gauze (mesh size = $1 \mathrm{~mm}^{2}$ ). We used 6 levels of light reduction ( 76 to $99 \%$ reduction of ambient sunlight), which differed in the number of gauze layers placed on top of the aquaria (each shading level was replicated twice). An extra layer of mesh, absorbing $76 \%$ of the incoming sunlight at the outdoor facilities, covered the entire experimental setup to avoid overheating of the aquaria and stress due to excessive insolation.

The water in all aquaria was exchanged daily to avoid nutrient depletion and accumulation of metabolic waste products. Over a $2 \mathrm{~d}$ period we measured oxygen concentrations in the aquaria 3 times a day (Oxymeter GOX 20; $\pm 0.2 \mathrm{mg} \mathrm{l}^{-1} \mathrm{O}_{2}$ ) at 12:00, 15:00 and 18:00 h. The absence of a diurnal rhythm in oxygen concentrations indicated that light reduction led to the cessation of photosynthesis and the minimum number of gauze layers at which this occurred was then considered as the shading regime closest to the LCP of the alga.

Light limitation phase. Algae were kept in an outdoor aquaria system with running seawater continuously pumped in from the nearby bay. Unfiltered seawater was pumped into two 551 storage tanks and filtered through mesh $(\sim 450 \mu \mathrm{m})$ to remove larger detritus particles. Both storage tanks were connected to 48 small plastic aquaria (2 1) with a constant flow of $\sim 25 \mathrm{l} \mathrm{h}^{-1}$ into each single aquarium. We equipped each of these aquaria with a constant air supply for additional water movement. The entire experimental setup was covered with a mesh that absorbed $76 \%$ of the incoming radiation. The shading regimes were established with different numbers of layers of black gauze material (mesh size $=1 \mathrm{~mm}^{2}$ ) mounted on top of the aquaria. Additionally, the aquaria were wrapped in aluminum foil to exclude scattered light coming in through the sidewalls. 
Algae were maintained at 6 different shading levels: one uncovered and exposed to the maximum light intensity prevailing under the mesh that permitted $24 \%$ of the incoming sunlight (maximum light), one close to the LCP and 2 levels above and 2 levels below the LCP. For each shading level, we used 4 aquaria where algae were exposed to grazing by Parhyalella penai ( 1 amphipod $g$ alga $^{-1}$ ). The 4 control aquaria (without $P$. penai) served to determine the autogenic change in the algae during the light limitation phase and to evaluate a possible defense induction by the seaweed. In the experiments with Lessonia nigrescens, we used a slightly different design with 4 shading levels and 5 replicates each. For this alga we had one maximum light regime and one above, one close to and one below the LCP. Since many shallow-water algae can cope with a temporary decrease or increase of available light (Markager \& Sand-Jensen 1992, Franklin \& Forster 1997), we exposed algae to low-light conditions for
$14 \mathrm{~d}$ to achieve an overall reduction of available resources. The number of grazers per aquarium was kept constant throughout the experiment by replacing missing individuals every third day.

Light intensities under the different shading regimes were quantified prior to the experiment with a photometer (LI-COR, Li-188B $\left[\mu \mathrm{mol} \mathrm{m} \mathrm{m}^{-2} \mathrm{~s}^{-1}\right]$ ); from this we calculated the amount of light blocked by the different numbers of gauze layers (Fig. 1). Shading regimes are therefore presented as percent light reduction from ambient sunlight (Fig. 1). Edding et al. (1990) found the incoming light in the sheltered bay of La Herradura, Coquimbo to be reduced by $90 \%$ at $7 \mathrm{~m}$ water depth in summer. Within a kelp bed, the common habitat of the 4 tested algal species, photosynthetically active radiation (PAR) can be reduced by 74 to $95 \%$ at $2.5 \mathrm{~m}$ depth (I. Gómez et al. unpubl. data from a Macrocystis integrifolia kelp bed, Isla Damas, Chile), comparable to the light conditions utilized in the present study.

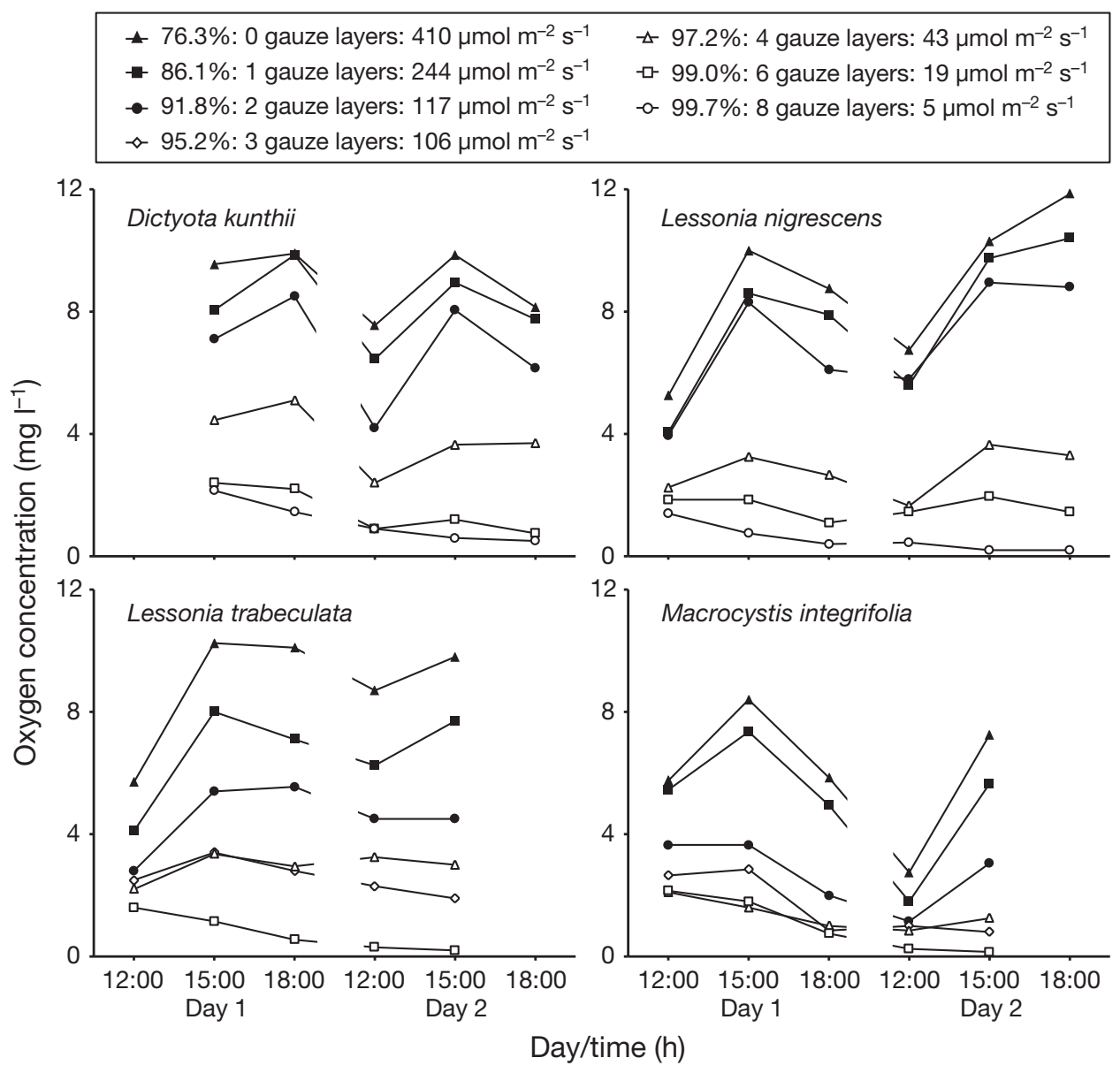

Fig. 1. Dictyota kunthii, Lessonia nigrescens, L. trabeculata and Macrocystis integrifolia. Oxygen production over a $48 \mathrm{~h}$ time period under different low-light regimes. Percentages represent the mean amount of ambient sunlight (measured on a clear day: $1716 \mu \mathrm{mol} \mathrm{m} \mathrm{m}^{-2} \mathrm{~s}^{-1}$ ) blocked by the protection net (0 gauze layers) and by the different numbers of additional gauze layers $(\mathrm{N}=3)$ 
We examined the direct effects of light reduction on algae by measuring the change in algal biomass under the different shading regimes in the presence and absence of grazers. Algal thalli were blotted with tissue paper to determine their wet weight (ShimadzuLibror EB-3200H $\pm 10 \mathrm{mg}$ ) at the beginning (initial wet weight) and at the end of the experiment (final wet weight).

Effects of light reduction on algal defenses. After the algae had been exposed to the different low-light conditions, we tested their palatability in no-choice feeding assays in which we offered either living algal tissue or reconstituted food pellets to the amphipod grazer Parhyalella penai (adult specimens, body length $\sim 4$ to $6 \mathrm{~mm}$ ). Due to the large number of replicates, we only conducted no-choice assays with food pellets and living algal tissue (accounting for autogenic changes of the algal tissues by growth controls) (Cronin \& Hay 1996d). Peterson \& Renaud (1989) suggested that results from no-choice assays can reliably reflect differences in attractiveness or palatability of various potential foods, which is also supported by recent studies (Toth \& Pavia 2007, Pansch et al. 2008). Furthermore, consumption data are independent of each other, as required for ANOVA. Living algal tissue and pellets were offered to $8 P$. penai in seawater-filled Petri dishes $(9 \mathrm{~cm}$ diameter, $\sim 80 \mathrm{ml}$ ). We allowed the amphipods to feed on the material for a maximum of $72 \mathrm{~h}$, and we exchanged seawater and replaced dead amphipods daily. Some assays were ended before this time to avoid total consumption of the algae. Consequently, the data from the feeding assays were converted into consumption rates as mg or squares consumed by $8 \mathrm{P}$. penai per $24 \mathrm{~h}$. We also tested for a bioactivity of algal extracts using the mussel species Perumytilus purpuratus and Semimytilus algosus. All assays were conducted in a constant temperature room $\left(15 \pm 1^{\circ} \mathrm{C}\right)$ with a $12 \mathrm{~h}$ light:12 $\mathrm{h}$ dark cycle at $40 \pm$ $10 \mu \mathrm{mol} \mathrm{m} \mathrm{m}^{-2} \mathrm{~s}^{-1}$ (40 W fluorescent lamp, Phillips).

Feeding assays with living algal material: For the assays with living material, we took 2 pieces of the basal blade ( $0.2 \mathrm{~g})$ from each alga. After blotting the algal pieces with absorbent tissue paper, we weighed them to the nearest $\mathrm{mg}( \pm 0.2 \mathrm{mg})$ before and after the feeding period. One algal piece from each replicate was left without grazers to measure autogenic changes in its biomass during the course of the assay. We calculated the biomass consumed by the herbivores $\left(\mathrm{C}_{\text {real }}\right)$ as $T_{i} \times\left(C_{f} / C_{i}\right)-T_{f}$, where $T_{i}$ and $T_{f}$ are the initial and final wet weights of the grazed algal pieces and $C_{i}$ and $\mathrm{C}_{\mathrm{f}}$ are the initial and final wet weights of the nongrazed control pieces, respectively (Cronin \& Hay 1996d).

Production of crude extracts: From the algae maintained in each aquarium, samples were collected to make extracts for food pellets and to load filter papers used in the mussel tests (Rothäusler et al. 2005, Medeiros et al. 2007). Excess seawater was removed from the alga ( $~ 8 \mathrm{~g}$ wet weight) by dabbing with tissue paper, and the thallus (including blades and stem) was then cut into small pieces to facilitate the extraction process. To obtain secondary metabolites within a wide range of polarities we extracted the pieces with 1:1 hexane-methanol (10 ml solvent $\left.\mathrm{g} \mathrm{alga}^{-1}\right)$ for $12 \mathrm{~h}$. This procedure was repeated at least 3 times until the solvent was visibly clear, followed by an additional extraction period of $12 \mathrm{~h}$. After evaporating the solvent and water, we used the remaining crude extract for the bioassays. To work with natural concentrations of the crude extract, we divided the dry weight of the extracted algal material by the dry weight of the filter paper used in the mussel test or the dry weight of the Ulva lactuca L. 1753 powder used for the pellet preparation. We then poured the appropriate amount of extract (extracted from $0.5 \mathrm{~g}$ algal dry weight) onto $0.5 \mathrm{~g}$ dry Ulva powder to prepare pellets or onto $0.5 \mathrm{~g}$ dry weight of the filter paper for the mussel test.

Feeding assays with food pellets: We prepared food pellets from Ulva powder, agar and crude algal extracts from all treatment levels. For this we re-dissolved the extract in a 1:1 hexane-methanol mix and added a defined amount, according to natural concentrations, to the Ulva powder. After the solvent had evaporated, the remaining extract-loaded Ulva powder was mixed with $6 \mathrm{ml}$ distilled water and $0.36 \mathrm{~g}$ warm fluid agar (max. $40^{\circ} \mathrm{C}$ ). We then poured the gel onto a plastic mesh consisting of 200 mesh squares of $1 \mathrm{~mm}^{2}$ each. Pressing this mass between 2 glass plates produced flat pellets which, after hardening, were offered to the grazers. Consumption rates were determined by counting the number of mesh squares (out of one pellet) consumed after the $24 \mathrm{~h}$ feeding period. Additionally, pellets that only contained Ulva powder served as a control. By comparing feeding rates on control pellets with those on extract-loaded pellets, we tested the effects of chemicals on herbivore grazing.

Mussel assays to test for bioactivity of algal extracts: Post-larvae and juvenile mussels are common intermittent colonizers on algal surfaces (Bayne 1964, Moreno 1995), and even though adult mussels rarely settle on seaweeds, they react to algal crude extracts (da Gama et al. 2003). We used a mussel assay (modified from da Gama et al. 2003) to screen for the bioactivity of algal extracts. Round discs (9 cm diameter) of coffee filter paper were soaked with redissolved algal extracts. Control paper discs were only loaded with solvent (1:1 hexane-methanol mix). After the solvent evaporated from the paper discs, we placed them in seawaterfilled Petri dishes ( $9 \mathrm{~cm}$ diameter, $\sim 80 \mathrm{ml}$ ). For each different algal extract we used 2 sub-replicates: 2 filter 
papers were loaded with the same extract but placed into separate Petri dishes to reduce variability by taking the mean from the 2 sub-replicates for further analyses. Immediately before the assays, mussels from the holding tanks were disaggregated by carefully cutting the byssus threads with scissors. To make sure that we only used healthy mussels, we exclusively selected individuals that showed substratum exploring behavior by actively exposing their foot and crawling after disaggregating. Three individuals were then placed into each dish and kept at $15 \pm 1{ }^{\circ} \mathrm{C}$ in total darkness for $24 \mathrm{~h}$, since mussels have been shown to be more active in the dark (Davis \& Moreno 1995). After $24 \mathrm{~h}$, we counted all byssus threads that were produced by the 3 mussels in a replicate, irrespective of whether these were attached to the filter paper, the walls of the Petri dish or to conspecifics. By comparing attachment rates in the presence of control filter paper (no extracts) to those in the presence of extract-loaded filter paper we determined whether chemicals were affecting mussel activity.

Statistical analysis. All data were tested for normality using the Shapiro-Wilk's $W$-test and were, if nonnormal, square-root transformed (arcsine transformation for percentage data) prior to the use of parametric statistical analyses. In the case of algal biomass change, we tested for a linear relationship between the increase in biomass and the shading level, using simple regression analysis, while biomass change in grazed and ungrazed algae was compared with an ANCOVA. We tested for differences in mean consumption rates by amphipods with a 2-way ANOVA including the factors shading (6 levels) and grazing status (2 levels). Byssus thread attachment rates in the presence of extracts were analyzed using a 3-way ANOVA with the factors shading (6 levels), grazing status (2 levels), and mussel species (2 levels). Homogeneity of variance was examined with a Bartlett's test and we used Fisher's least significant difference (LSD) test for multiple comparisons following ANOVA. For data obtained in assays with Dictyota kunthii, transformation did not lead to normally distributed data. Since ANOVA is relatively robust against violation of the assumption of normally distributed data (Underwood 1997), we proceeded with the parametric analysis, but lowered the $\alpha$-level from 0.05 to 0.01 (Wakefield \& Murray 1998). Additionally, we compared consumption rates on reconstituted food between extractloaded and control pellets as well as byssus attachment rates on extract-loaded and only solvent-treated filter papers. We separately compared all single treatments with the control using Dunnett's test (Dunnett 1955); the $\alpha$-level for significant results for this test was lowered to 0.01 when normal distribution was not achieved after transformation.

\section{RESULTS}

\section{Light compensation points}

Diurnal patterns in oxygen concentrations allowed us to identify the shading regime closest to each algae's LCP (Fig. 1). For Dictyota kunthii, Lessonia nigrescens and $L$. trabeculata the LCP was between 91.8 and $97.2 \%$ light reduction, i.e. under 2 and 4 layers of gauze, respectively. The LCP of Macrocystis integrifolia, however, was between 91.8 and $95.2 \%$ light reduction, corresponding to 2 and 3 gauze layers, respectively. On the basis of these results, we used $97.2 \%$ light reduction for $D$. kunthii, $L$. nigrescens and L. trabeculata and $95.2 \%$ light reduction for M. integrifolia as thresholds for shading levels.

\section{Algal biomass change during the light limitation phase}

After the phase of light reduction, all 4 algal species showed a significant decrease in biomass change with increasing shade (Fig. 2). Most algae individuals exhibited necrosis in the apical parts at shading levels below their LCP, which was also reflected in negative biomass changes. While most Dictyota kunthii died under $99.7 \%$ light reduction, some Lessonia nigrescens grew even under these extreme conditions. Under maximum light availability $(\sim 76 \%$ reduction of ambient sunlight), all D. kunthii, $L$. nigrescens and $L$. trabeculata were in healthy condition and showed up to $80 \%$ biomass accrual within $14 \mathrm{~d}$. Massive loss of tissue was observed for some individuals of Macrocystis integrifolia, while other individuals of the same species grew up to $60 \%$ within $2 \mathrm{wk}$. Among all algae investigated, the giant kelp exhibited the highest variability in biomass change over the shading gradient. Generally, grazed algae showed feeding marks (mainly on apical parts) irrespective of the shading treatment (pers. obs.), but a significant difference in biomass changes between grazed and ungrazed algal individuals was only found for $L$. trabeculata $(\mathrm{ANCOVA}, \mathrm{df}=1, \mathrm{MS}=$ $0.001, F=20.263, \mathrm{p} \leq 0.001$ ).

\section{Amphipod consumption of algal material after the light limitation phase}

Feeding assays with living material of Dictyota kunthii revealed no significant differences in mean consumption rates between the different shading levels for both previously grazed and ungrazed algal individuals. The same was true in assays with reconstituted 

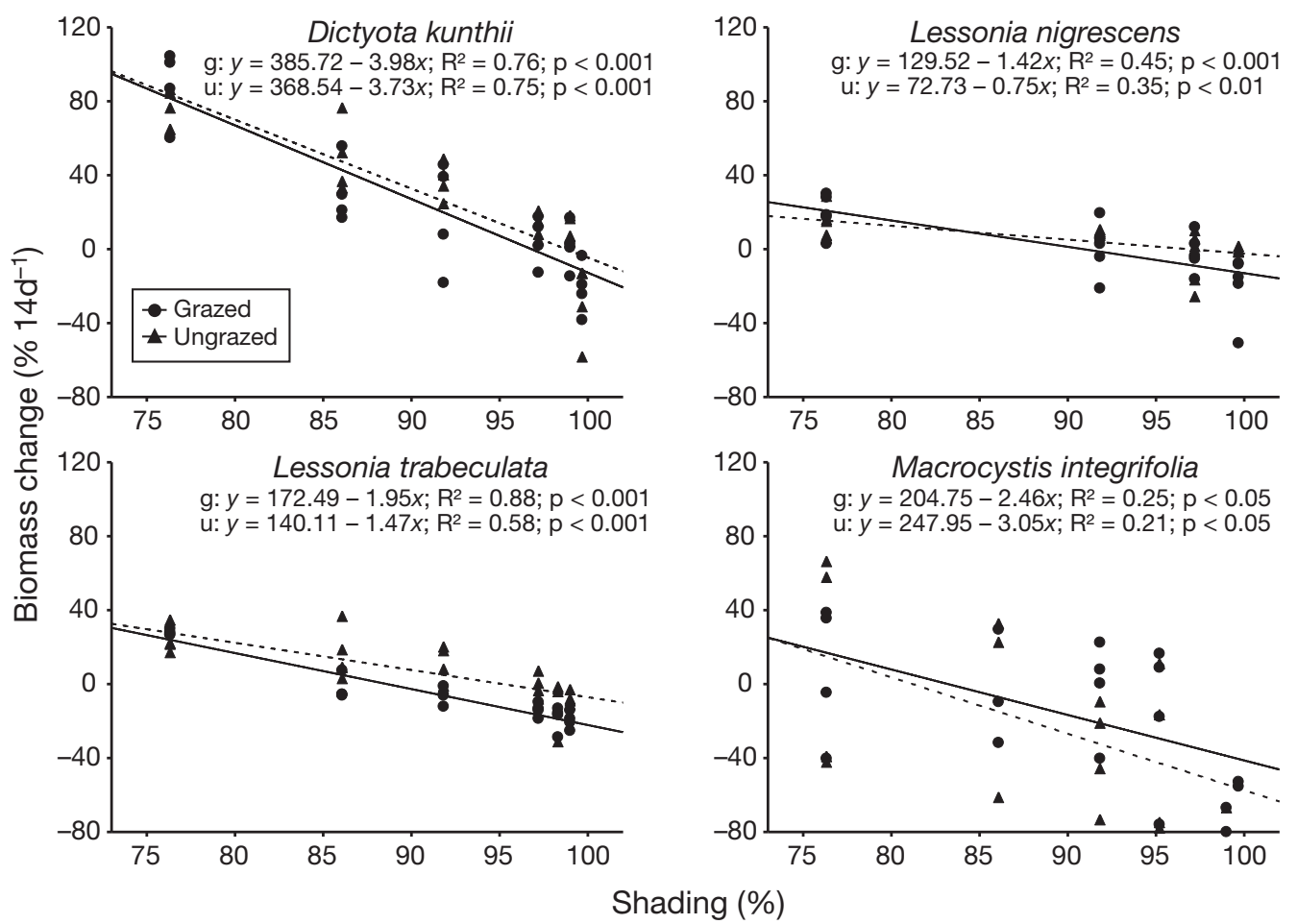

Fig. 2. Dictyota kunthii, Lessonia nigrescens, L. trabeculata and Macrocystis integrifolia. Relationship between change in algal biomass (for algae maintained with $[\mathrm{g}]$ and without $[\mathrm{u}]$ grazers) and shading after $14 \mathrm{~d}$ of light limitation

food made from this alga (Table 1, Fig. 3). Comparisons between amphipod feeding on pellets containing extracts and consumption of pellets containing only Ulva powder (controls) revealed that controls were significantly preferred (Dunnett's test, $\mathrm{p} \leq 0.05$ ).

In assays with Lessonia nigrescens, we observed a significant interaction between shading and grazing status and generally higher consumption rates on more shaded algae (Table 1, Fig. 3). In the $97.2 \%$ shading level, previously ungrazed algal individuals were more attractive to amphipod mesograzers than grazed individuals. Consumption of grazed material from the 76.3, 91.8 and $97.2 \%$ shading levels was significantly lower than on previously grazed individuals that experienced

Table 1. Parhyalella penai. Effects of shading and grazing on the consumption of algal material observed in 2 different feeding assays: living algal material and reconstituted food pellets containing crude extracts (2-way ANOVA). Significant results in bold

\begin{tabular}{|c|c|c|c|c|c|c|c|c|}
\hline \multirow[t]{2}{*}{ Alga } & \multirow[t]{2}{*}{ Source of variation } & \multirow[t]{2}{*}{ df } & \multicolumn{3}{|c|}{ Living algal material } & \multicolumn{3}{|c|}{ Reconstituted food pellets } \\
\hline & & & MS & $F$ & $\mathrm{p}$ & MS & $F$ & $\mathrm{p}$ \\
\hline \multirow[t]{3}{*}{ Dictyota kunthii } & Shading level (S) & 5 & 0.462 & 1.602 & 0.184 & 0.795 & 1.282 & 0.294 \\
\hline & Grazing (G) & 1 & 0.029 & 0.101 & 0.752 & 0.509 & 0.819 & 0.372 \\
\hline & $\mathrm{S} \times \mathrm{G}$ & 5 & 0.425 & 1.475 & 0.222 & 0.242 & 0.389 & 0.853 \\
\hline \multirow{3}{*}{ Lessonia nigrescens } & Shading level (S) & 3 & 29.128 & 8.199 & $<0.001$ & 5.280 & 6.209 & $<0.01$ \\
\hline & Grazing (G) & 1 & 37.780 & 10.634 & $<0.01$ & 0.171 & 0.201 & 0.657 \\
\hline & $\mathrm{S} \times \mathrm{G}$ & 3 & 10.330 & 2.908 & $<0.05$ & 0.849 & 0.998 & 0.406 \\
\hline \multirow[t]{3}{*}{ Lessonia trabeculata } & Shading level (S) & 5 & 0.793 & 0.404 & 0.843 & 0.003 & 0.421 & 0.831 \\
\hline & Grazing (G) & 1 & 4.239 & 2.158 & 0.150 & 0.002 & 0.343 & 0.562 \\
\hline & $\mathrm{S} \times \mathrm{G}$ & 5 & 2.273 & 1.157 & 0.349 & 0.005 & 0.768 & 0.579 \\
\hline \multirow[t]{3}{*}{ Macrocystis integrifolia } & Shading level (S) & 3 & 0.416 & 0.194 & 0.899 & 1.106 & 1.523 & 0.243 \\
\hline & Grazing (G) & 1 & 0.885 & 0.412 & 0.529 & 2.327 & 3.203 & 0.090 \\
\hline & $\mathrm{S} \times \mathrm{G}$ & 3 & 0.139 & 0.065 & 0.978 & 1.317 & 1.813 & 0.181 \\
\hline
\end{tabular}


Living algal material

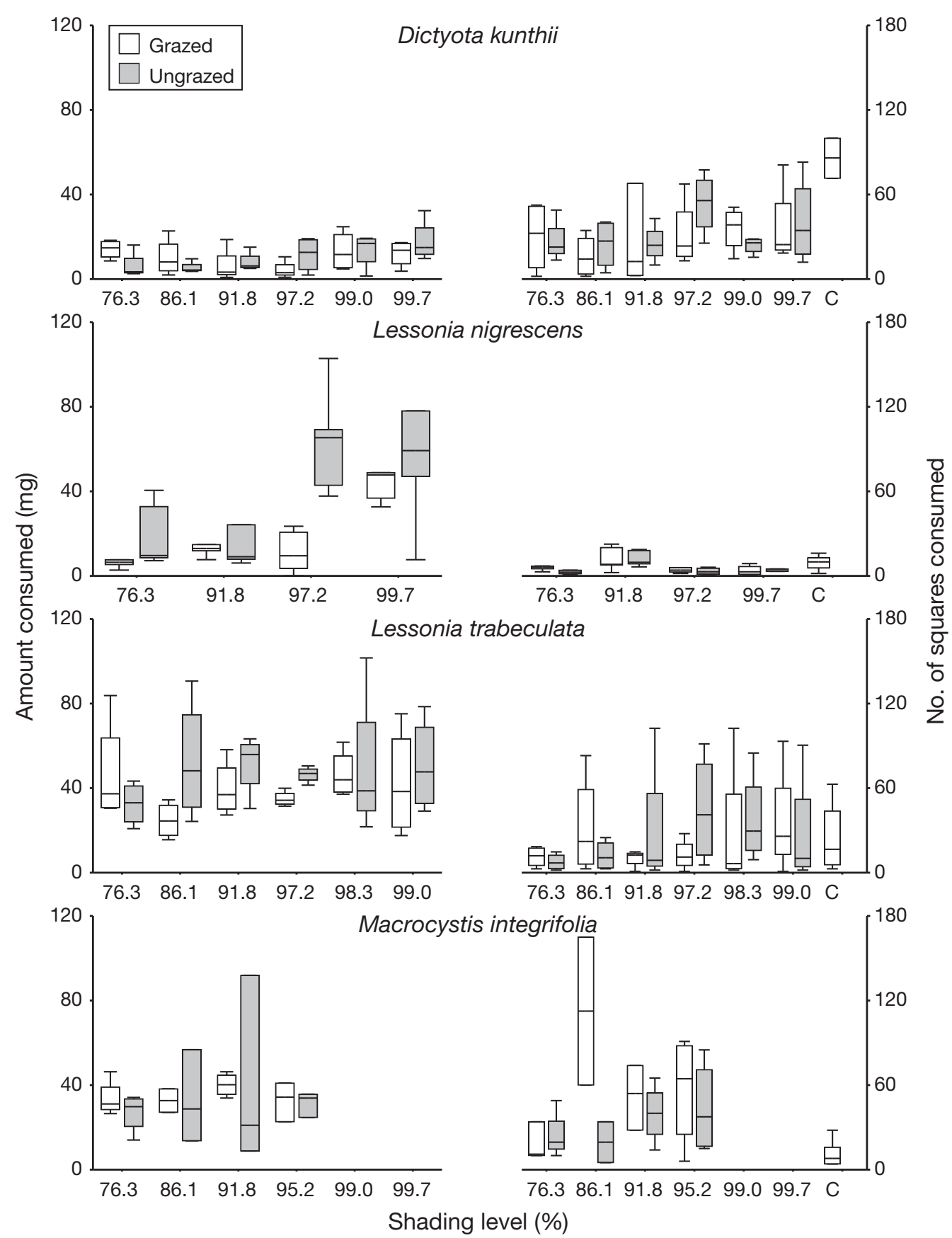

Fig. 3. Parhyalella penai. Consumption rates (mg or squares) of material from Dictyota kunthii, Lessonia nigrescens, L. trabeculata and Macrocystis integrifolia (by 8 amphipods per $24 \mathrm{~h}$ ) after the light limitation phase in feeding assays with living material and reconstituted food pellets containing polar and non-polar algal extracts. Consumption rates are given for each shading regime on grazed (white bars) and ungrazed (grey bars) algal material. Box and whisker plots: each bar shows median (horizontal line), 1st and 3rd quartiles (boxes) and non-outlier minimum and maximum values (whiskers). C: Ulva control pellets, i.e. pellets without algal extract

99.7 \% light reduction (Fisher's LSD, $\mathrm{p} \leq 0.05$ ). In the assays with the food pellets made from $L$. nigrescens, we detected that the amount consumed differed significantly between shading levels, while there was neither an effect of the grazing history nor an interaction be- tween the 2 factors (Table 1). Grazed as well as ungrazed algal material that experienced $91.8 \%$ light reduction was most attractive (Fig. 3). However, no gradual increase in consumption with increasing shade occurred. Pellets containing extracts appeared less at- 
tractive than the controls, but these differences were not significant (Dunnett's test, $\mathrm{p}>0.05)$.

For Lessonia trabeculata, we observed no effects of light reduction or grazing history on amphipod consumption (Table 1, Fig. 3). Feeding on extract-loaded and control pellets did not differ significantly (Dunnett's test, $\mathrm{p}>0.05)$. Due to drastic biomass losses in several individuals of Macrocystis integrifolia at the 2 most extreme shading levels (99.0 and $99.7 \%$ ), we could only include the benign and intermediate shading levels $(76.3,86.1,91.8$ and $95.2 \%)$ in the analysis, and no significant differences in consumption rates, either in assays with living material or with artificial food, emerged. Grazing history also had no influence on the palatability of giant kelp (Table 1, Fig. 3). Comparing amphipod feeding on extract-loaded and control pellets showed that, in general, the loaded food was more attractive, but a significant difference was found only between the controls and the 86.1\% shading level in case of previously ungrazed algal individuals ( $p \leq 0.05)$.
Table 2. Influence of light reduction, grazing pressure and mussel species on byssus thread production within the $24 \mathrm{~h}$ long mussel tests (3-way ANOVA; the $\alpha$-level was lowered to 0.01 for Dictyota kunthii). Significant results in bold

\begin{tabular}{|c|c|c|c|c|c|}
\hline & Source of variation & $\mathrm{df}$ & MS & $F$ & $\mathrm{p}$ \\
\hline Dictyota & Shading level (S) & 5 & 121.880 & 2.931 & 0.018 \\
\hline \multirow[t]{6}{*}{ kunthii } & Grazing (G) & 1 & 0.940 & 0.023 & 0.881 \\
\hline & Mussel species (M) & 1 & 248.648 & 5.980 & 0.017 \\
\hline & $\mathrm{S} \times \mathrm{G}$ & 5 & 18.071 & 0.435 & 0.823 \\
\hline & $\mathrm{S} \times \mathrm{M}$ & 5 & 82.930 & 1.994 & 0.090 \\
\hline & $\mathrm{G} \times \mathrm{M}$ & 1 & 0.940 & 0.023 & 0.881 \\
\hline & $\mathrm{S} \times \mathrm{G} \times \mathrm{M}$ & 5 & 17.459 & 0.420 & 0.833 \\
\hline \multirow{7}{*}{$\begin{array}{l}\text { Lessonia } \\
\text { nigrescens }\end{array}$} & Shading level (S) & 3 & 4.748 & 4.062 & $<0.01$ \\
\hline & Grazing (G) & 1 & 0.304 & 0.260 & 0.612 \\
\hline & Mussel species (M) & 1 & 401.657 & 343.6 & $<0.001$ \\
\hline & $\mathrm{S} \times \mathrm{G}$ & 3 & 3.773 & 3.228 & $<0.05$ \\
\hline & $\mathrm{S} \times \mathrm{M}$ & 3 & 1.291 & 1.104 & 0.354 \\
\hline & $\mathrm{G} \times \mathrm{M}$ & 1 & 0.005 & 0.005 & 0.946 \\
\hline & $\mathrm{S} \times \mathrm{G} \times \mathrm{M}$ & 3 & 0.406 & 0.347 & 0.791 \\
\hline \multirow{7}{*}{$\begin{array}{l}\text { Lessonia } \\
\text { trabeculata }\end{array}$} & Shading level (S) & 5 & 0.972 & 1.001 & 0.424 \\
\hline & Grazing (G) & 1 & 0.373 & 0.384 & 0.538 \\
\hline & Mussel species (M) & 1 & 24.595 & 25.313 & $<0.001$ \\
\hline & $\mathrm{S} \times \mathrm{G}$ & 5 & 1.377 & 1.417 & 0.229 \\
\hline & $\mathrm{S} \times \mathrm{M}$ & 5 & 1.038 & 1.068 & 0.385 \\
\hline & $\mathrm{G} \times \mathrm{M}$ & 1 & 0.074 & 0.076 & 0.783 \\
\hline & $\mathrm{S} \times \mathrm{G} \times \mathrm{M}$ & 5 & 0.676 & 0.696 & 0.628 \\
\hline \multirow{7}{*}{$\begin{array}{l}\text { Macrocystis } \\
\text { integrifolia }\end{array}$} & Shading level (S) & 3 & 0.982 & 0.865 & 0.466 \\
\hline & Grazing (G) & 1 & 4.277 & 3.767 & 0.059 \\
\hline & Mussel species (M) & 1 & 24.890 & 21.921 & $<0.001$ \\
\hline & $\mathrm{S} \times \mathrm{G}$ & 3 & 1.843 & 1.623 & 0.198 \\
\hline & $\mathrm{S} \times \mathrm{M}$ & 3 & 0.157 & 0.139 & 0.936 \\
\hline & $\mathrm{G} \times \mathrm{M}$ & 1 & 2.233 & 1.967 & 0.168 \\
\hline & $\mathrm{S} \times \mathrm{G} \times \mathrm{M}$ & 3 & 1.838 & 1.619 & 0.199 \\
\hline
\end{tabular}

\section{Effects of light reduction on bioactivity against mussels}

Tests in which we investigated the influence of extracts from Dictyota kunthii on the byssus attachment activity of the 2 mussels showed no significant influence of any of the tested factors (Table 2). Extracts from $D$. kunthii generally led to extremely low rates of byssus attachment, but attachment rates by both mussel species increased in response to algal extracts from algal individuals held under 99.7\% light reduction (Fig. 4). Attachment rates of Semimytilus algosus and Perumytilus purpuratus to controls were significantly higher than to filter paper soaked with algal extracts regardless of the treatment combination (Dunnett's test, $\mathrm{p} \leq 0.01$ ).

With extracts from Lessonia nigrescens, we found that byssus production differed significantly among shading levels and between mussel species. Additionally, we found a significant interaction between shading and grazing history, while there was no significant main effect of the latter (Table 2, Fig. 4). Attachment of Semimytilus algosus in response to grazed material from $91.8 \%$ shading differed significantly from 76.3 , 97.2 and $99.7 \%$ shading (grazed) and from 76.3 and 99.7\% shading (ungrazed) (Fisher's LSD, p $\leq 0.05$ ). In Perumytilus purpuratus, 99.7\% shading (grazed and ungrazed) differed significantly from $91.8 \%$ (grazed) and from $97.2 \%$ shading (ungrazed); 99.7\% shading (ungrazed) also differed from 76.3\% (ungrazed) ( $\mathrm{p} \leq$ 0.05). However, attachment rates of both mussel species did not differ between the controls and loaded filter paper regardless of shading level and grazing status (Dunnett's test, $\mathrm{p}>0.05$ ).

In assays with Lessonia trabeculata and Macrocystis integrifolia, the 2 mussel species differed significantly in byssus production, while all other factors were insignificant (Table 2, Fig. 4). For M. integrifolia, we again only included the moderate shading regimes $(76.3,86.1,91.8$ and $95.2 \%)$ in the analysis. While the activity of Perumytilus purpuratus did not differ in the presence or absence of extracts from either algal species (Dunnett's test, p > 0.05), Semimytilus algosus attached significantly more byssus threads to control filter papers than in response to extracts in several treatment combinations ( $\mathrm{p} \leq 0.05)$. 


\section{Semimytilus algosus Perumytilus purpuratus}
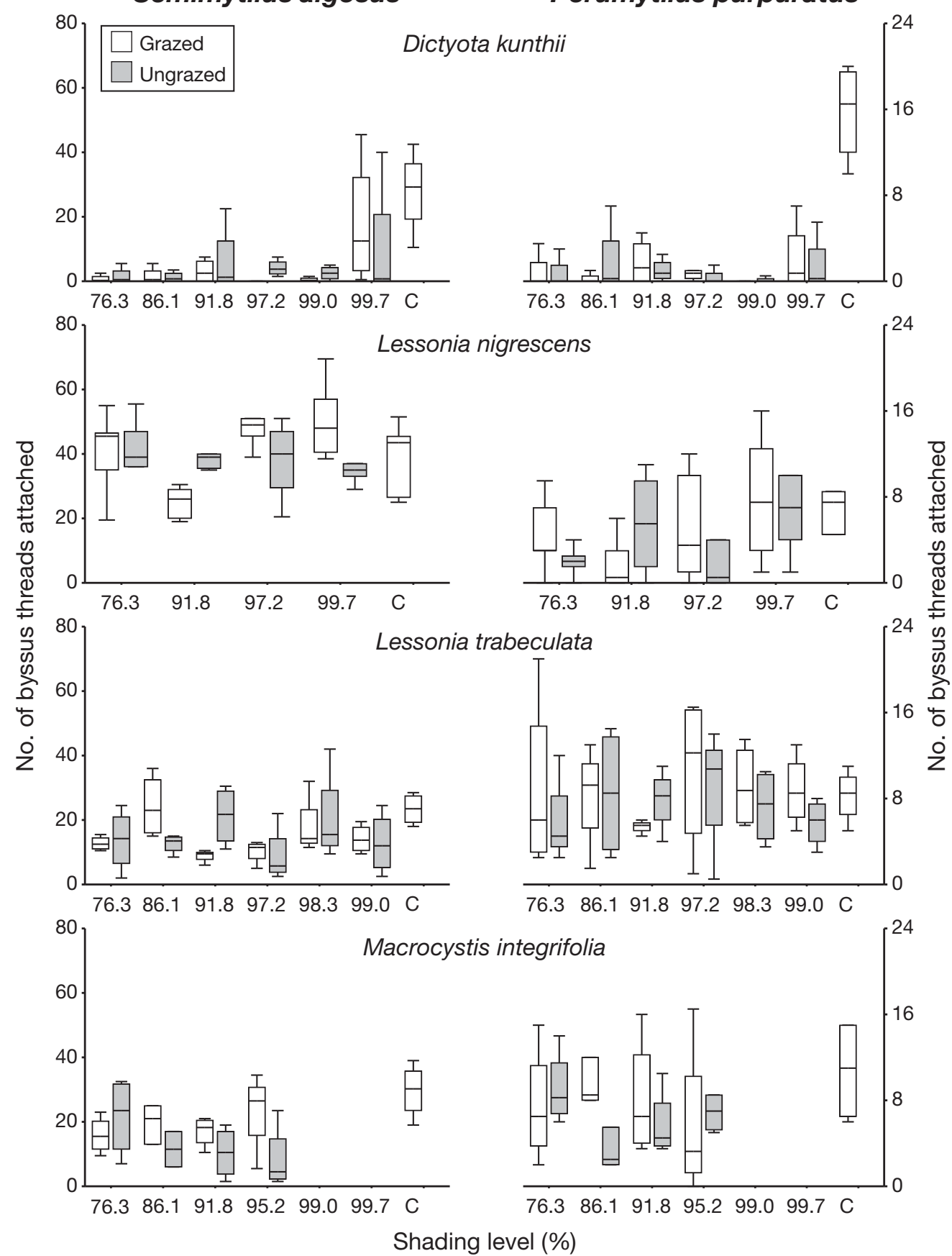

Fig. 4. Semimytilus algosus and Perumytilus purpuratus. Number of byssus threads attached after 24 h by 3 individuals of the 2 mussel species in the presence of extracts from the algae Dictyota kunthii, Lessonia nigrescens, L. trabeculata and Macrocystis integrifolia across the shading gradient. Attachment rates are given on extracts of grazed (white bars) and ungrazed (grey bars) algae. Box and whisker plots as in Fig. 3. C: solvent control filter papers, i.e. without algal extracts

\section{DISCUSSION}

The significant decrease in biomass change with decreasing light availability in all 4 seaweed species indicates that our treatment impaired the primary metabolism of the algae. However, light reduction barely affected deterrent effects (if present) against the amphipod Parhyalella penai and its bioactivity against the 2 macrofoulers Semimytilus algosus and Perumytilus purpuratus. While chemical defenses, if present, remained unaffected, some of our results indicate that the palatability of the algae increased under 
severe but non-lethal low-light conditions, presumably due to a change in the nutritional or structural quality of algal tissue. Furthermore, results point to 2 different strategies of how seaweeds might cope with light limitation.

\section{Palatability of living algal material and of reconstituted food}

The finding of anti-herbivore defense in Dictyota kunthii supports previous studies which showed that secondary metabolites, such as pachydictyol-A from $D$. kunthii (de Nys et al. 1993) and other Dictyotales (Paul et al. 2001), can efficiently deter various invertebrates (Paul 1992, Amsler \& Fairhead 2005 and references therein). Interestingly, in the present study this defense remained unaffected by severe light limitation. However, a slight increase in feeding rates occurred in assays with algal material (living and reconstituted) from $99.7 \%$ shading, where all algal individuals died off. This suggests that D. kunthii maintains defenses until exceeding lethal low-light conditions. Moreover, it needs to be considered that during decomposition bacterial growth might increase on algal surfaces (Weinberger et al. 1994), positively affecting the palatability of the alga after death (due to, for example, changes in chemicals or $\mathrm{C}: \mathrm{N}$ ratios).

Light limitation strongly affects carbon fixation (Stamp 2004 and references therein) and thus seems to lead to a reduction of the defense capabilities of the alga Lessonia nigrescens. This is in line with assumptions from the widely accepted growth-differentiation balance hypothesis, which predicts a decrease in defenses when energy is scarce, e.g. due to reduced photosynthesis under low-light conditions (Stamp 2004). The fact that grazed L. nigrescens under severe light reduction in the present study were less palatable than ungrazed conspecifics is in line with observations made by Rothäusler \& Thiel (2006), who reported that detached $L$. nigrescens maintained defense traits longer when they were grazed. We suggest that the presence of herbivores forces algae to maintain defenses even under severe shading conditions to avoid the risk of substantial tissue loss. If light is limited, the loss of photosynthetically active tissue might reduce individual fitness more drastically than when energy is plentiful. An enhanced defensive status in those tissues seems therefore plausible to ensure that carbon fixation does not drop below a minimum threshold. Such an adaptation would be the response to a specific combination of stressors.

Comparisons of the results from both feeding assays suggest that the consumption patterns observed in assays with living algal material were independent of chemicals. Thus, predictions from the growth-differentiation balance hypothesis (Stamp 2004) seem to be true for a structurally mediated defense but, interestingly, not for a chemical defense. Nutritional traits might also have influenced feeding by Parhyalella penai in fresh feeding assays, since tissue of low nutritional quality (from severe shading levels) could have forced the amphipods to overcompensate for energy deficiency by higher feeding rates (Cruz-Rivera \& Hay 2000, 2003). More likely, structural traits, e.g. tissue toughness, that constitute a mechanical defense (Littler \& Littler 1980) were compromised under low-light conditions, facilitating shredding and consumption of living algal parts by the mesograzers. This loss in tissue rigidity of living algal tissues could be due to changes within the alginate structure (mannuronic and guluronic acids) or due to a loss of cell turgor. Furthermore, phlorotannins are assumed to complex with alginic acid (Schoenwaelder \& Clayton 1999). Thus, effects on phlorotannin production within the organism might have also influenced algal structure. Earlier investigations demonstrated that a higher attractiveness of live Lessonia nigrescens for herbivorous snails and fish was correlated with lower tissue-phlorotannin contents (Martinez 1996), while our results suggest that, in this species, chemicals play a minor or even no role in the defense against grazing. However, $L$. nigrescens has a robust tissue structure, since it is adapted to resist strong wave action in exposed intertidal habitats (Santelices et al. 1980), which should be effective in deterring amphipod mesograzers such as the amphipod $P$. penai-at least when energy is not limited.

Jackson (1987) showed that Macrocystis pyrifera is very susceptible to light reduction, which also appears valid for $M$. integrifolia, since in the present study several individuals of this species died off under low-light regimes. Interestingly, defensive traits were not negatively affected by light limitation. This indicates that defense, if present, was held constant or was rather ineffective in deterring amphipod grazers. The higher consumption of the extract-loaded pellets made from $M$. integrifolia compared to the controls suggests that chemicals of the giant kelp might have stimulated grazing by Parhyalella penai rather than deterring it. This has also recently been observed in another study (Pansch et al. 2008). Since M. integrifolia is exposed to a wide variety of grazing organisms (North 1994), it is surprising that this alga apparently does not express a chemical defense against mesograzers at least in its apical vegetative blades. However, comparatively low consumption and high phlorotannin concentrations were found in basal reproductive blades (Pansch et al. 2008). The lack of defense in vegetative blades is supported by findings of Steinberg (1985) and Winter \& 
Estes (1992), showing low phenolic contents in vegetative tissue of the congener M. pyrifera. Irelan \& Horn (1991) furthermore showed that polar extracts from $M$. integrifolia, incorporated in food pellets, had no influence on the feeding behavior of the herbivorous fish Cebidichthys violaceus. We therefore hypothesize that the strategy of this alga is to overcompensate for herbivory by growth rather than repelling grazers by defensive traits. Accordingly, in the present study we observed high biomass accrual in algae grown under ambient light conditions, and previous studies also reported very high growth rates for Macrocystis spp., reaching about $5 \%$ of the average thallus length per day (Gerard 1982, Stekoll \& Else 1990).

General differences in feeding rates on grazed and ungrazed material were observed for Lessonia nigrescens (in fresh feeding assays) but remained undetected for the other algal species. This is surprising since an inducible defense against amphipods was previously reported for Dictyota kunthii in the same study system (Macaya et al. 2005, Rothäusler et al. 2005, Rothäusler \& Thiel 2006). Discrepancies between the present and previous studies should, however, not be due to differences in the methods used (i.e. performing choice or no-choice assays). We are convinced that the results of the no-choice feeding assays in the present study reflect algal palatability reliably, since several recent studies have shown that no-choice assays produce similar outcomes as choice assays (Taylor et al. 2002, Macaya et al. 2005, Wessels et al. 2006, Macaya \& Thiel 2008), as also confirmed by a recent meta-analysis (Toth \& Pavia 2007).

In general, we found that the small, delicate alga Dictyota kunthii has a strong chemical defense against amphipod grazing, while such a defense was weak or absent in the large kelp species which might escape consumption by thallus growth. Furthermore, in the large kelps Lessonia nigrescens or $L$. trabeculata, whiplash effects, i.e. movements of fronds and stipes due to water movement, might provide protection against grazers in intertidal and shallow subtidal habitats (Dayton et al. 1984, Santelices \& Ojeda 1984).

\section{Effects of algal crude extracts on mussel activity}

The strong bioactivity of extracts from Dictyota kunthii against the 2 mussel species coincides with results reported for the congener $D$. menstrualis. For the latter species, Schmitt et al. (1995) revealed a chemical deterrence against bryozoan larvae mediated by compounds like pachydictyol-A, which is also present in $D$. kunthii (de Nys et al. 1993). Our results indicate that either the bioactivity against mussels was not negatively influenced by low-light stress or that the respec- tive compounds were very effective even at very low concentrations. An increase in attachment rates only occurred at the $99.7 \%$ shading level (for both mussel species), where all $D$. kunthii died off. Since chemical deterrence was weak in the large kelp species (Lessonia nigrescens, L. trabeculata and Macrocystis integrifolia), we suspect other mechanisms to mediate resistance against epibionts. Whiplash effects may not only protect efficiently against mesograzers (see also above), but also rub off sessile organisms from algal surfaces. This mechanical effect may act in synergy with chemical deterrence in some species, though at present we have no knowledge about this.

The ecological relevance of the applied extraction procedure, i.e. whole-cell extraction, has been recently questioned (Nylund et al. 2007), because most fouling organisms will rarely come into contact with compounds from within the algal cells. However, the purpose of the mussel test was not to mimic natural situations but rather to test whether these algae produced any chemical deterrents, and whether the production or activity of these chemicals might be influenced by the light reduction the algae experienced. Previous studies have shown the mussel test to be a reliable ecological proxy for algal defenses (da Gama et al. 2003). Since some epibionts penetrate deep into the algal tissue (e.g. Leonardi et al. 2006) the mussel test may also offer hints of activity against some (but not all) epibionts.

\section{CONCLUSIONS}

We showed that light reduction strongly suppressed growth in all algal species, i.e. energy limitation affected primary life processes, but most deterring effects in algal extracts tested in the present study were not affected by non-lethal light reduction. However, light limitation altered the characteristics of living algal tissues (e.g. nutritional or structural traits), resulting in a higher palatability to amphipod grazers (e.g. Lessonia nigrescens). Overall, the results of the present study with 4 brown macroalgae from the northern-central Chilean coast provide little support for the hypothesis that chemical defense is reduced under non-lethal conditions of resource limitation. Thus, the particular predictions from the growth-differentiation balance hypothesis and the environmental stress theory need to be reconsidered, specifically in regard to light reduction for photosynthetically active organisms, at least for chemically mediated defenses.

Our data suggest that different algae follow different strategies when exposed to strong light reduction (Fig. 5). In the present study, Lessonia nigrescens exhibited a weak decrease in biomass over the shading 


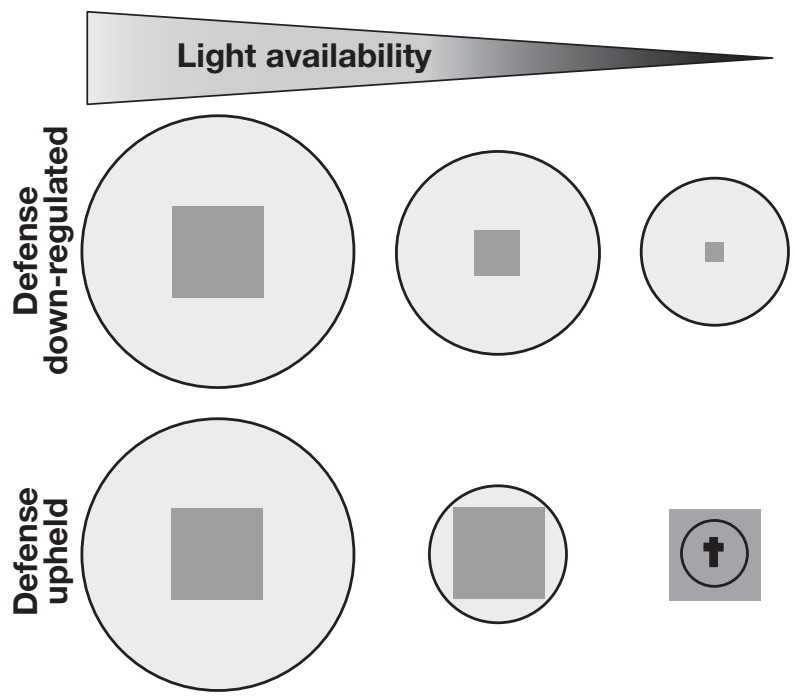

Photosynthesis Photosynthesis Photosynthesis

\begin{tabular}{l}
\hline Maintenance, growth Defense thethal conditions \\
and reproduction
\end{tabular}

Fig. 5. Suggested model for defense strategies in seaweeds under light limitation: Seaweeds either down-regulate defense traits under non-lethal low-light conditions but maintain biomass (e.g. Lessonia nigrescens), or uphold defense while comprising primary traits as growth (e.g. Dictyota kunthii)

gradient even at very high shading levels, and was the only alga that apparently lost defenses at high shading levels. This species may down-regulate defense in order to maintain basic life functions. In contrast, Dictyota kunthii seems to uphold its defenses until death. This alga showed an extreme negative slope of biomass change across the entire shading gradient, which suggests that $D$. kunthii reduces growth while maintaining defense. Thus, our results suggest that, under low-light conditions, algae may either down-regulate defense or compromise growth. However, this assumption needs to be tested in future studies.

Acknowledgements. We are thankful for the use of the Marine Botany Laboratory at the Universidad Católica del Norte, Coquimbo. We also thank C. P. Dumont for his help in planning and performing the experiment, and I. Goméz and 3 anonymous reviewers for helpful comments on the manuscript. This project was financed by the Mercator Stiftung GmbH (M.L. and M.W.), and through FONDECYT 1060127 (M.T.).

\section{LITERATURE CITED}

Amsler CD (2001) Induced defenses in macroalgae: the herbivore makes the difference. J Phycol 37:353-356

> Amsler CD, Fairhead VA (2005) Defensive and sensory chemical ecology of brown algae. Adv Bot Res 43:1-91
Arnold TM, Targett NM (1998) Quantifying in situ rates of phlorotannin synthesis and polymerization in marine brown algae. J Chem Ecol 24:577-595

> Arnold TM, Targett NM (2003) To grow and defend: lack of tradeoffs for brown algal phlorotannins. Oikos 100: 406-408

$>$ Bayne BL (1964) Primary and secondary settlement in Mytilus edulis L. (Mollusca). J Anim Ecol 33:513-523

Cancino JM, Muñoz J, Muñoz M, Orellana MC (1987) Effects of the bryozoan Membranipora tuberculata (Bosc.) on the photosynthesis and growth of Gelidium rex Santelices et Abbott. J Exp Mar Biol Ecol 113:105-112

Cronin G (2001) Resource allocation in seaweed and marine invertebrates: chemical defense patterns in relation to defense theories. In: McClintock JB, Baker BJ (eds) Marine chemical ecology. CRC Press, Boca Raton, FL, p 325-353

Cronin G, Hay ME (1996a) Susceptibility to herbivores depends on recent history of both the plant and animal. Ecology 77:1531-1543

Cronin G, Hay ME (1996b) Induction of seaweed chemical defenses by amphipod grazing. Ecology 77:2287-2301

> Cronin G, Hay ME (1996c) Effects of light and nutrient availability on the growth, secondary chemistry and resistance to herbivory of two brown seaweeds. Oikos 77:93-106

Cronin G, Hay ME (1996d) Within-plant variation in seaweed palatability and chemical defenses: optimal defense theory versus the growth-differentiation balance hypothesis. Oecologia 105:361-368

Cruz-Rivera E, Hay ME (2000) Can quantity replace quality? Food choice, compensatory feeding, and fitness of marine mesograzers. Ecology 81:201-219

Cruz-Rivera E, Hay ME (2003) Prey nutritional quality interacts with chemical defenses to affect consumer feeding and fitness. Ecol Monogr 73:483-506

da Gama BAP, Pereira RC, Soares AR, Teixeira VL, Yoneshigue-Valentin Y (2003) Is the mussel test a good indicator of antifouling activity? A comparison between laboratory and field assays. Biofouling 19:161-169

Davis AR, Moreno CA (1995) Selection of substrata by juvenile Choromytilus chorus (Mytilidae): Are chemical cues important? J Exp Mar Biol Ecol 191:167-180

Dayton PK, Currie V, Gerrodette T, Keller BD, Rosenthal R, Ven Tresca D (1984) Patch dynamics and stability of some Californian kelp communities. Ecol Monogr 54: 253-289

de Nys R, Wright AD, König GM, Sticher O (1993) A diterpene from the marine alga Glossophora kunthii. Phytochemistry 32:463-465

Dethier MN, Williams SL, Freeman A (2005) Seaweeds under stress: manipulated stress and herbivory affect critical lifehistory functions. Ecol Monogr 75:403-418

Dixon J, Schroeter SC, Kastendiek J (1981) Effects of the encrusting bryozoan, Membranipora membranacea, on the loss of blades and fronds by the giant kelp, Macrocystis pyrifera (Laminariales). J Phycol 17:341-345

$>$ Duffy JE, Hay ME (1990) Seaweed adaptation to herbivory. Bioscience 40:368-375

$>$ Duffy JE, Paul VJ (1992) Prey nutritional quality and effectiveness of chemical defenses against tropical reef fishes. Oecologia 90:333-339

- Dunnett CW (1955) A multiple comparison procedure for comparing several treatments with a control. J Am Stat Assoc 50:1096-1121

Dworjanyn SA, Wright JT, Paul NA, de Nys R, Steinberg PD (2006) Cost of chemical defence in the red alga Delisea pulchra. Oikos 113:13-22 
Edding M, Venegas M, Orrego P, Fonck E (1990) Culture and growth of Lessonia trabeculata (Phaeophyta, Laminariales) juvenile sporophytes in La Herradura de Guayacan Bay, northern Chile. Hydrobiologia 204-205:361-366

Fagerström T (1989) Anti-herbivore chemical defense in plants: a note on the concept of cost. Am Nat 133:281-287

Franklin LA, Forster RM (1997) The changing irradiance environment: consequences for marine macrophyte physiology, productivity and ecology. Eur J Phycol 32:207-232

Gerard VA (1982) Growth and utilization of internal nitrogen reserves by the giant kelp Macrocystis pyrifera in a lownitrogen environment. Mar Biol 66:27-35

Gómez I, Orostegui M, Huovinen P (2007) Morpho-functional patterns of photosynthesis in the south Pacific kelp Lessonia nigrescens: effects of UV radiation on ${ }^{14} \mathrm{C}$ fixation and primary photochemical reactions. J Phycol 43:55-64

Haggitt TR, Babcock RC (2003) The role of grazing by the lysianassid amphipod Orchomenella aahu in dieback of the kelp Ecklonia radiata in north-eastern New Zealand. Mar Biol 143:1201-1211

Irelan CD, Horn MH (1991) Effects of macrophyte secondary chemicals on food choice and digestive efficiency of Cebidichthys violaceus (Gerard), an herbivorous fish of temperate marine waters. J Exp Mar Biol Ecol 153: 179-194

Jackson GA (1987) Modelling the growth and harvest yield of the giant kelp Macrocystis pyrifera. Mar Biol 95:611-624

Jennings JG, Steinberg PD (1997) Phlorotannin versus other factors affecting epiphyte abundance on the kelp Ecklonia radiata. Oecologia 109:461-473

Jormalainen V, Honkanen T (2008) Macroalgal chemical defenses and their roles in structuring temperate marine communities. In: Amsler CD (ed) Algal chemical ecology. Springer-Verlag, Berlin, Heidelberg, p 57-89

Lane AL, Kubanek J (2008) Secondary metabolite defenses against pathogens and biofoulers. In: Amsler CD (ed) Algal chemical ecology. Springer-Verlag, Berlin, Heidelberg, p 229-243

> Lau SCK, Qian PY (1997) Phlorotannins and related compounds as larval settlement inhibitors of the tube building polychaete Hydroides elegans. Mar Ecol Prog Ser 159: 219-227

> Lau SCK, Qian PY (2000) Inhibitory effect of phenolic compounds and marine bacteria on larval settlement of the barnacle Balanus amphitrite amphitrite Darwin. Biofouling 16:47-58

Leonardi PI, Miravalles AB, Faugeron S, Flores V, Beltrán J, Correa JA (2006) Diversity, phenomenology and epidemiology of epiphytism in farmed Gracilaria chilensis (Rhodophyta) in northern Chile. Eur J Phycol 41: 247-257

Littler MM, Littler DS (1980) The evolution of thallus form and survival strategies in benthic marine macroalgae: field and laboratory tests of a functional form model. Am Nat 116:25-44

Lubchenco J, Gaines SD (1981) A unified approach to marine plant-herbivore interactions. I. Populations and communities. Annu Rev Ecol Syst 12:405-437

Macaya EC, Thiel M (2008) In situ tests on inducible defenses in Dictyota kunthii and Macrocystis integrifolia (Phaeophyceae) from the Chilean coast. J Exp Mar Biol Ecol 354:28-38

Macaya EC, Rothäusler E, Thiel M, Molis M, Wahl M (2005) Induction of defenses and within-alga variation of palatability in two brown algae from the northern-central coast of Chile: effects of mesograzers and UV radiation. J Exp Mar Biol Ecol 325:214-227
Markager S, Sand-Jensen K (1992) Light requirements and depth zonation of marine macroalgae. Mar Ecol Prog Ser 88:83-92

> Martinez EA (1996) Micropopulation differentiation in phenol content and susceptibility to herbivory in the Chilean kelp Lessonia nigrescens (Phaeophyta, Laminariales). Hydrobiologia 326-327:205-211

Maschek JA, Baker BJ (2008) The chemistry of algal secondary metabolism. In: Amsler CD (ed) Algal chemical ecology. Springer-Verlag, Berlin, Heidelberg, p 1-24

> Mattson WJ (1980) Herbivory in relation to plant nitrogen content. Annu Rev Ecol Syst 11:119-161

Medeiros HE, da Gama BAP, Gallerani G (2007) Antifouling activity of seaweed extracts from Guarujá, Sao Paulo, Brazil. Braz J Oceanogr 55:257-264

> Moreno CA (1995) Macroalgae as a refuge from predation for recruits of the mussel Choromytilus chorus (Molina, 1782) in southern Chile. J Exp Mar Biol Ecol 191: 181-193

North WJ (1994) Macrocystis. In: Akatsuka WJ (ed) Biology of economic algae. SPB Academic Publishing, The Hague, Netherlands, p 407-446

> Nylund GM, Gribben PE, de Nys R, Steinberg PD, Pavia H (2007) Surface chemistry versus whole-cell extracts: antifouling tests with seaweed metabolites. Mar Ecol Prog Ser 329:73-84

> Pansch C, Gómez I, Rothäusler E, Veliz K, Thiel M (2008) Species-specific defense strategies of vegetative versus reproductive blades of the Pacific kelps Lessonia nigrescens and Macrocystis integrifolia. Mar Biol 155:51-62

Paul VJ (1992) Seaweed chemical defenses on coral reefs. In: Paul VJ (ed) Ecological roles of marine natural products. Comstock Publishing, Ithaca, NY, p 24-50

Paul VJ, Cruz-Rivera E, Thacker RW (2001) Chemical mediation of macroalgal-herbivore interactions: ecological and evolutionary perspectives. In: McClintock JB, Baker BJ (eds) Marine chemical ecology. CRC Press, Boca Raton, FL, p 227-265

> Pavia H, Toth GB (2000) Influence of light and nitrogen on the phlorotannin content of the brown seaweeds Ascophyllum nodosum and Fucus vesiculosus. Hydrobiologia 440: 299-305

Pavia H, Toth GB (2008) Macroalgal models in testing and extending defense theories. In: Amsler CD (ed) Algal chemical ecology. Springer-Verlag, Berlin, Heidelberg, p 147-172

Pavia H, Toth GB, Aberg P (1999) Trade-offs between phlorotannin production and annual growth in natural populations of the brown seaweed Ascophyllum nodosum. J Ecol 87:761-771

Peterson CH, Renaud PE (1989) Analysis of feeding preference experiments. Oecologia 80:82-86

Rhoades DF (1979) Evolution of plant chemical defense against herbivores. In: Rosenthal GA, Janzen DH (eds) Herbivores: their interaction with secondary plant metabolites. Academic Press, New York, p 4-54

$>$ Rhoades DF (1985) Offensive-defensive interactions between herbivores and plants: their relevance in herbivore population dynamics and ecological theory. Am Nat 125: 205-238

> Rothäusler E, Thiel M (2006) Effect of detachment on the palatability of two kelp species. J Appl Phycol 18: 423-435

Rothäusler E, Macaya EC, Molis M, Wahl M, Thiel M (2005) Laboratory experiments examining inducible defense show variable responses of temperate brown and red macroalgae. Rev Chil Hist Nat 78:603-614 
Saier B, Chapman AS (2004) Crusts of the alien bryozoan Membranipora membranacea can negatively impact spore output from native kelps (Laminaria longicruris). Bot Mar 47:265-271

Santelices B, Ojeda FP (1984) Recruitment, growth and survival of Lessonia nigrescens (Phaeophyta) at various tidal levels in exposed habitats of central Chile. Mar Ecol Prog Ser 19:73-82

Santelices B, Castilla JC, Cancino J, Schmiede P (1980) Comparative ecology of Lessonia nigrescens and Durvillaea antarctica (Phaeophyta) in Central Chile. Mar Biol 59: $119-132$

Schmitt TM, Hay ME, Lindquist N (1995) Constraints on chemically mediated coevolution: multiple functions for seaweed secondary metabolites. Ecology 76:107-123

Schoenwaelder MEA, Clayton MN (1999) The presence of phenolic compounds in isolated cell walls of brown algae. Phycologia 38:161-166

Seed R (1985) Ecological pattern in the epifaunal communities of coastal macroalgae. In: Moore PG, Seed R (eds) The ecology of rocky coasts. Hodder \& Stoughton, London, p 22-25

Stamp N (2003) Out of the quagmire of plant defense hypotheses. Q Rev Biol 78:23-55

Stamp N (2004) Can the growth-differentiation balance hypothesis be tested rigorously? Oikos 107:439-448

Steinberg PD (1985) Feeding preferences of Tegula funebralis and chemical defenses of marine brown algae. Ecol Monogr 55:333-349

Steinberg PD (1995) Seasonal variation in the relationship between growth rate and phlorotannin production in the kelp Ecklonia radiata. Oecologia 102:169-173

Steinberg PD, de Nys R (2002) Chemical mediation of colonization of seaweed surfaces. J Phycol 38:621-629

Editorial responsibility: James McClintock, Birmingham, Alabama, USA
Stekoll MS, Else PV (1990) Cultivation of Macrocystis integrifolia (Laminariales, Phaeophyta) in southeastern Alaskan waters. Hydrobiologia 204-205:445-451

> Taylor RB, Sotka E, Hay ME (2002) Tissue-specific induction of herbivore resistance: seaweed response to amphipod grazing. Oecologia 132:68-76

Toth GB, Pavia H (2007) Induced herbivore resistance in seaweeds: a meta-analysis. J Ecol 95:425-434

Underwood AJ (1997) Experiments in ecology: their logical design and interpretation using statistical principles. Cambridge University Press, Cambridge

Van Dam NM, De Jong TJ, Iwasa Y, Kubo T (1996) Optimal distribution of defenses: are plants smart investors. Funct Ecol 10:128-136

Véliz K, Edding M, Tala F, Gómez I (2006) Effects of ultraviolet radiation on different life cycle stages of the south $\mathrm{Pa}$ cific kelps, Lessonia nigrescens and Lessonia trabeculata (Laminariales, Phaeophyceae). Mar Biol 149: 1015-1024

Wakefield RL, Murray SN (1998) Factors influencing food choice by the seaweed-eating marine snail Norrisia norrisi (Trochidae). Mar Biol 130:631-642

- Weinberger F, Friedlander M, Gunkel W (1994) A bacterial facultative parasite of Gracilaria conferta. Dis Aquat Org 18:135-141

Wessels H, Hagen W, Molis M, Wiencke C, Karsten U (2006) Intra- and interspecific differences in palatability of Arctic macroalgae from Kongsfjorden (Spitsbergen) for two benthic sympatric invertebrates. J Exp Mar Biol Ecol 329: 20-33

Winter FC, Estes JA (1992) Experimental evidence for the effects of polyphenolic compounds from Dictyoneurum californicum (Phaeophyta; Laminariales) on feeding rate and growth in the red abalone (Haliotus rufescens). J Exp Mar Biol Ecol 155:263-277

Submitted: August 20, 2008; Accepted: January 22, 2009 Proofs received from author(s): April 6, 2009 